\title{
Article \\ Comparative Studies on the Susceptibility of (R)-2,3-Dipalmitoyloxypropylphosphonocholine (DPPnC) and Its Phospholipid Analogues to the Hydrolysis or Ethanolysis Catalyzed by Selected Lipases and Phospholipases
}

\author{
Paweł Mituła ${ }^{1}$, Czesław Wawrzeńczyk ${ }^{2}$ and Witold Gładkowski ${ }^{2, *(\mathbb{D})}$ \\ 1 Institute of Environmental Engineering, Wroclaw University of Environmental and Life Sciences, \\ Grunwaldzki Square 24, 50-363 Wroclaw, Poland; pawel.mitula@upwr.edu.pl \\ 2 Department of Chemistry, Wroclaw University of Environmental and Life Sciences, Norwida 25, \\ 50-375 Wroclaw, Poland; czeslaw.wawrzenczyk@upwr.edu.pl \\ * Correspondence: witold.gladkowski@upwr.edu.pl; Tel.: +48-713205154
}

\section{check for}

updates

Citation: Mituła, P.; Wawrzeńczyk, C.; Gładkowski, W. Comparative Studies on the Susceptibility of $(R)-2,3-$ Dipalmitoyloxypropylphosphonocholine (DPPnC) and Its Phospholipid Analogues to the Hydrolysis or Ethanolysis Catalyzed by Selected Lipases and Phospholipases. Catalysts 2021, 11, 129. https://doi.org/ $10.3390 /$ catal11010129

Received: 22 December 2020 Accepted: 14 January 2021 Published: 16 January 2021

Publisher's Note: MDPI stays neutral with regard to jurisdictional clai$\mathrm{ms}$ in published maps and institutional affiliations.

Copyright: (C) 2021 by the authors. Licensee MDPI, Basel, Switzerland. This article is an open access article distributed under the terms and conditions of the Creative Commons Attribution (CC BY) license (https:// creativecommons.org/licenses/by/ $4.0 /)$.

\begin{abstract}
Susceptibility of soybean phosphatidylcholine, 1,2-dipalmitoyl-sn-glycero-3-phosphocholine (DPPC) and its phosphono analogue (R)-2,3-dipalmitoyloxypropylphosphonocholine (DPPnC) towards selected lipases and phospholipases was compared. The ethanolysis of substrates at $s n-1$ position was carried out by lipase from Mucor miehei (Lipozyme ${ }^{\circledR}$ ) and lipase B from Candida antarctica (Novozym 435) in $95 \%$ ethanol at $30^{\circ} \mathrm{C}$, and the hydrolysis with Lecitase ${ }^{\mathrm{TM}}$ Ultra was carried out in hexane/water at $50{ }^{\circ} \mathrm{C}$. Hydrolysis at $s n-2$ position was carried out in isooctane/Tris- $\mathrm{HCl} / \mathrm{AOT}$ system at $40^{\circ} \mathrm{C}$ using phospholipase $\mathrm{A}_{2}\left(\mathrm{PLA}_{2}\right)$ from porcine pancreas and PLA $\mathrm{A}_{2}$ from bovine pancreas or $25^{\circ} \mathrm{C}$ using $\mathrm{PLA}_{2}$ from bee venom. Hydrolysis in the polar part of the studied compounds was carried out at $30^{\circ} \mathrm{C}$ in acetate buffer/ethyl acetate system using phospholipase D (PLD) from Streptococcus sp. and PLD from white cabbage or in Tris- $\mathrm{HCl}$ buffer/methylene chloride system at $35{ }^{\circ} \mathrm{C}$ using PLD from Streptomyces chromofuscus. The results showed that the presence of C-P bond between glycerol and phosphoric acid residue in DPPnC increases the rate of enzymatic hydrolysis or ethanolysis of ester bonds at the $s n-1$ and $s n-2$ position and decreases the rate of hydrolysis in the polar head of the molecule. The most significant changes in the reaction rates were observed for reaction with PLD from Streptococcus sp. and PLD from Streptomyces chromofuscus that hydrolyzed DPPnC approximately two times slower than DPPC and soybean PC. The lower susceptibility of DPPnC towards enzymatic hydrolysis by phospholipases D gives hope for the possibility of using DPPnC-like phosphonolipids as the carriers of bioactive molecules that, instead of choline, can be bounded with diacylpropylphosphonic acids (DPPnA).
\end{abstract}

Keywords: phosphonolipids; phospholipids; enzymatic hydrolysis; lipases; phospholipases

\section{Introduction}

Phosphonolipids (PnLs) are one of the most interesting groups of lipids. In nature, phosphonolipids can be found in many species of microorganisms, marine organisms [1-3] and hen's egg [4]. They are components of the cell membrane that ensure its stability. Phosphonolipids facilitate the movement of DNA [5], and some of them are inhibitors of enzymes [6,7].

Natural phosphonolipids possess the C-P bond on the polar (choline) side of the molecule. For this reason, the first syntheses and the biological studies were carried out on phosphonolipids, which are esters of 2-aminoethylphosphonic acid with diacylglycerol or with $N$-acylsphingosine [8-10]. At the beginning of the 21st century, Prestwich research group synthesized some phosphonolipids with C-P bond on hydrophobic (glycerol) side. They obtained a wide variety of phosphono analoges of 2-lysophosphatidic acid [11-13], which showed activity as long-lived receptor-specific agonists and antagonists for LPA 
receptors. As inhibitors of the lysophospholipase D activity, they can be useful in therapy of cancer disease $[14,15]$.

A few years ago, we also reported the synthesis of a series of phosphonolipids with C-P bond on a glycerol side. They contained different fatty acid residues and choline in their structure [16]. We have been planning to compare their biological activity, mainly cytotoxic, with the activity of corresponding phosphatydylcholines. In our research plans, there is also a use of phosphonolipids as drug carriers. Before starting these studies, it is necessary to check their susceptibility towards hydrolytic enzymes involved in the first step of lipid metabolism, namely lipases and phospholipases.

Lipases and phospholipases are environmentally friendly biocatalysts that catalyze the hydrolysis of ester bonds of triacylglycerols and phospholipids, respectively. Besides hydrolytic activity, lipases also catalyze esterification and transesterification reaction [17]. Phospholipases also show esterification and transphosphatidylation activity [18]. Moreover, these biocatalysts have broad substrate specificity, high enantioselectivity and stability in organic solvents and at extreme temperatures and $\mathrm{pH}$ [19]. They are commonly used in the synthesis of structured lipids with different physical and/or nutritional properties [20]. Thus, lipases and phospholipases have found application in fine chemistry, pharmacy, agriculture, food industry and cosmetics [21,22].

Here, for the first time, we present the results of comparable studies on the hydrolysis (or ethanolysis) of 1,2-dipalmitoyl-sn-glycero-3-phosphocholine (DPPC) and its phosphono analogue (R)-2,3-dipalmitoyloxypropylphosphonocholine (DPPnC) catalyzed by selected lipases and phospholipases.

\section{Results and Discussion}

In order to compare the susceptibility of phosphonolipids and phospholipids to the selected hydrolytic enzymes, the same absolute configurations of model substrates, namely DPPC and its phosphono analogue DPPnC, is required. As DPPC was synthesized from sn-glycero-3-phosphocholine (GPC), with a retention typical for natural phospholipids " $R$ " configuration at $\mathrm{C}-2$, in the first step of our research we needed to synthesize $(R)$-enantiomer of DPPnC.

\subsection{Synthesis of (R)-2,3-Dipalmitoyloxypropylphosphonocholine (DPPnC, 4)}

Synthesis of $(R)$-DPPnC (4) is shown in Scheme 1 . The key step of this procedure was regioand enantioselective hydrolysis of racemic diethyl 2,3-dipalmitoyloxypropylphosphonate (1), which was obtained as described in our previous paper [16]. The reaction was catalyzed by phospholipase $\mathrm{A}_{2}$ from porcine pancreas in isooctane/Tris- $\mathrm{HCl}$ system $(\mathrm{pH}=8.5)$ in the presence of AOT and $\mathrm{Ca}^{2+}$ ions. In these conditions, diethyl (R)-2-hydroxy-3palmitoyloxypropylphosphonate (2) was obtained at $22 \%$ yield.

Enantiomeric excesses of $(R)$-2-hydroxyphosphonate 2 and unreacted ( $S$ )-substrate 1 were determined by HPLC with application of chiral column (Figure 1). This analysis indicated 19\% ee of unreacted (S)-diethyl 2,3-dipalmitoyloxypropylphosphonate ((S)-1) (Figure 1C) and $87 \%$ ee of the desired product of hydrolysis (2), which was analyzed after its esterification with palmitic acid to (R)-diethyl 2,3-dipalmitoyloxypropylphosphonate 1 (Figure 1B). Absolute configuration " $R$ " of 2-hydroxyphosphonate 2 obtained after phospholipase $\mathrm{A}_{2}$-catalyzed hydrolysis of rac-1 was confirmed by comparison of optical rotation of known [23] $(R)$-diol $3\left([\alpha]_{D}^{25}=-12.2\right.$ (c 4.1, EtOH)) with the optical rotation of diol $3\left([\alpha]_{D}^{20}=-8.7(\mathrm{c} 0.4, \mathrm{EtOH})\right)$ obtained as the product of hydrolysis of $(R)-2$ hydroxyphosphonate 2 with $\mathrm{KOH}$ in $\mathrm{MeOH}$ (Scheme 1). 


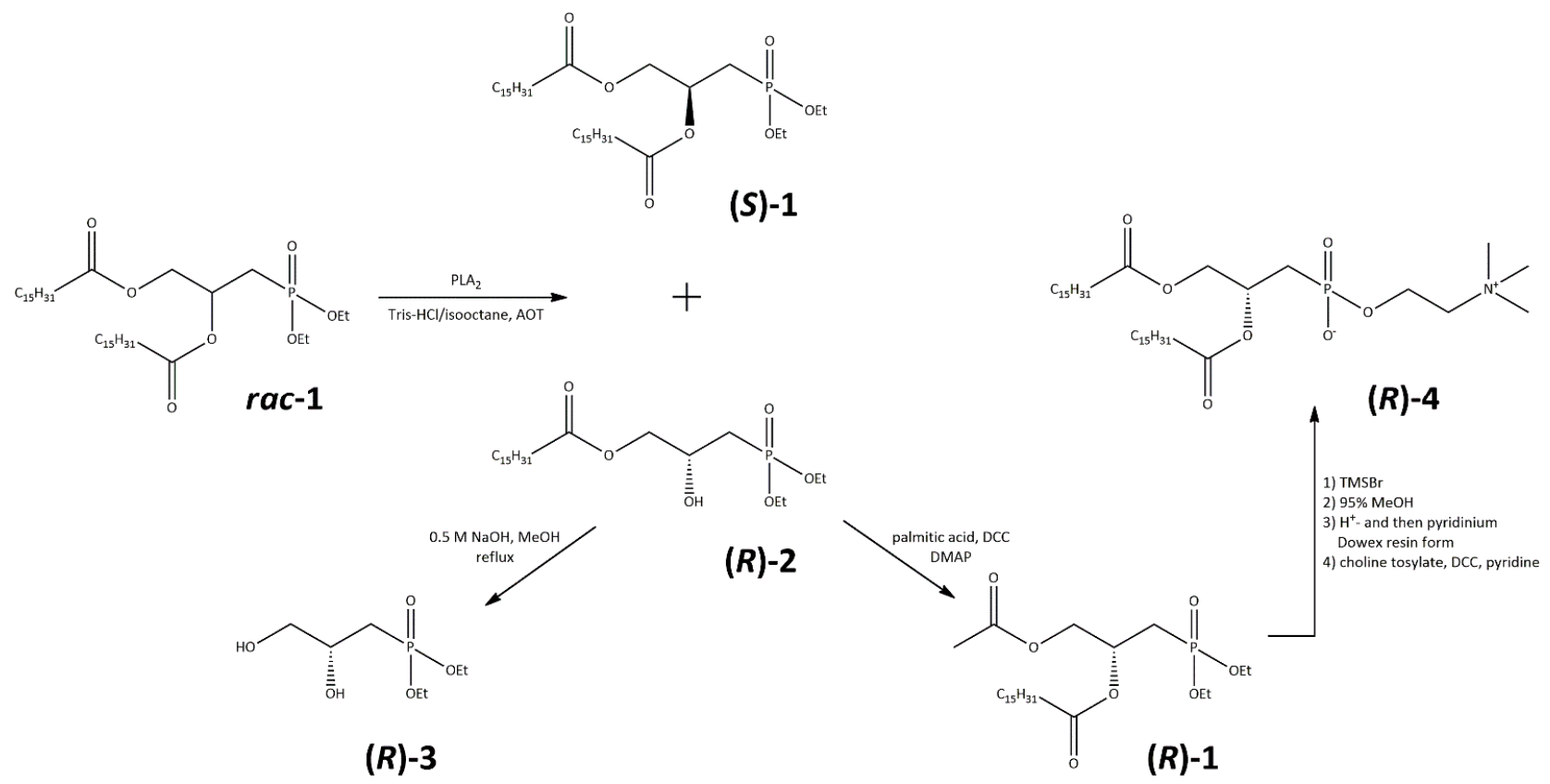

Scheme 1. Synthesis of (R)-2,3-dipalmitoyloxypropylphosphonocholine (4).

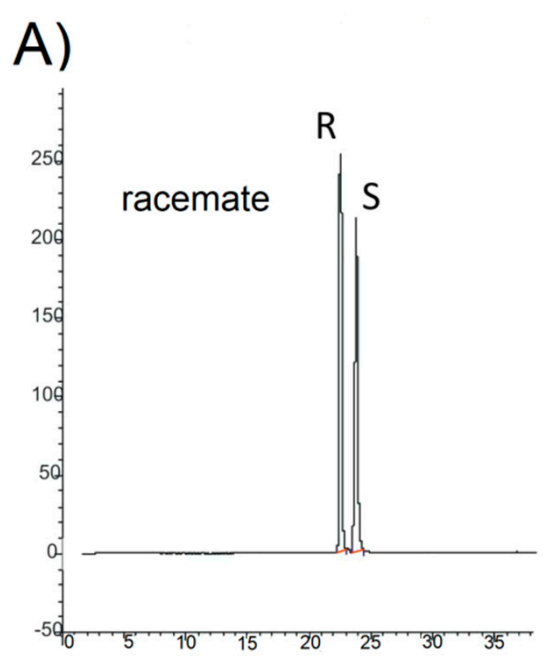

B)

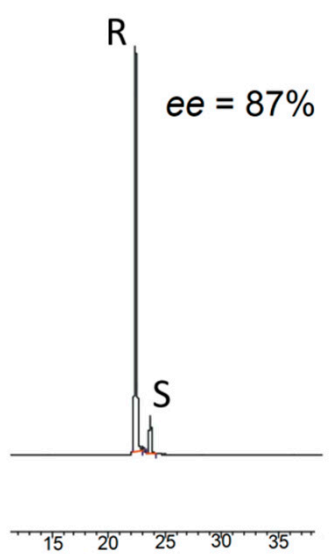

C)

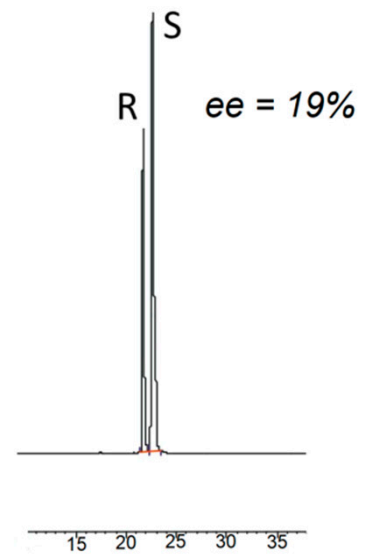

Figure 1. Chromatograms from chiral HPLC analysis of racemic diethyl 2,3-dipalmitoyloxypropylphosphonate (1) (A) and the products of $\mathrm{PLA}_{2}$-catalyzed hydrolysis of racemic phosphonate 1: (R)-hydroxyphosphonate 2 (analyzed after derivatization to $(R)$-phosphonate 1) (B) and unreacted (S)-phosphonate (1) (C).

Enantiomerically enriched $(R)$-2-hydroxyphosphonate 2 was the starting material in the four-step synthesis of target phosphonolipid, (R)-DPPnC (4). In the first step, hydroxy group at C-2 in (R)-2-hydroxyphosphonate 2 was esterified with palmitic acid via Steglich method to afford ( $R$ )-diethyl 2,3-dipalmitoyloxypropylphosphonate $\mathbf{1}$ in $94 \%$ yield. (R)-Phosphonate 1 was sillylated using TMSBr, followed by methanolysis to afford $(R)$-phosphonic acid, which, in the form of pirydinium salt, was subjected to the reaction with choline tosylate to produce (R)-DPPnC (4). The total yield of synthesis of 4 from $(R)$ phosphonate 1 was $51 \%$. The described synthetic pathway, established earlier for racemic 2,3-diacyloxypropylphosphonocholines [16], ensured the retention of $R$ configuration for final phosphonolipid 4. 


\subsection{Enzymatic Reactions of Soybean PC, DPPC and DPPnC with Selected Lipases and Phospholipases}

To test the susceptibility of synthesized phosphonolipid to the hydrolytic enzymes, in each experiment we compared the results of DPPnC hydrolysis with its phospholipid counterpart as well as with natural soybean PC. The detailed results are given in Tables S1-S3, and the progress of reactions is presented in Figures 2-4. For each enzyme treatment, the control experiment without the addition of enzyme was carried out to check the stability of substrates in the reaction conditions.
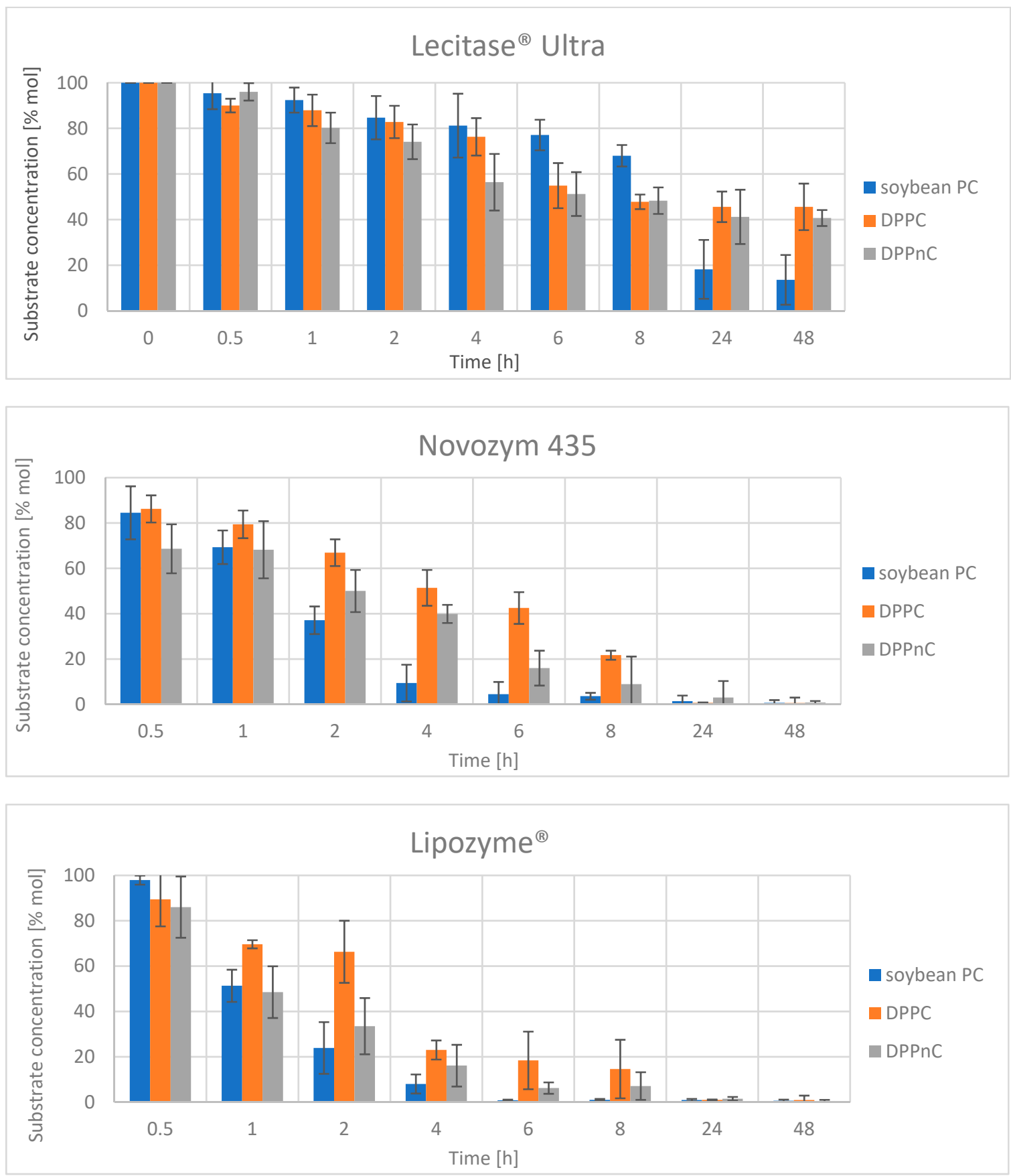

Figure 2. Enzymatic reactions of DPPnC, DPPC and soybean PC in $s n-1$ position. Results are presented as means \pm standard deviation. 

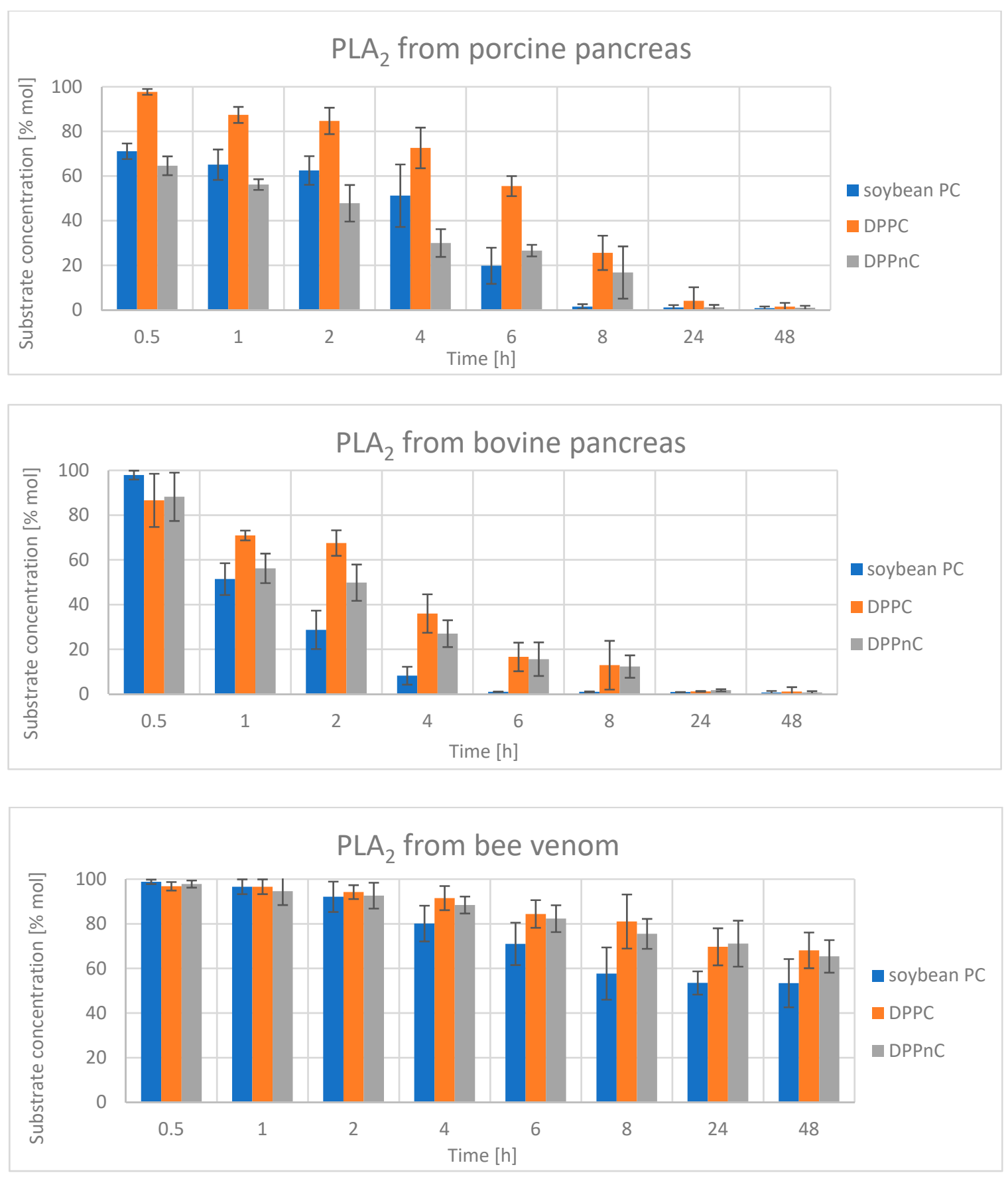

Figure 3. Enzymatic hydrolysis of DPPnC, DPPC and soybean PC by phospholipases $\mathrm{A}_{2}$. Results are presented as means \pm standard deviation.

\subsubsection{Reactions at $s n-1$ Position}

In the first set of experiments, enzymes selective towards $s n-1$ position of natural phospholipids were used: lipase from Mucor miehei (Lipozyme ${ }^{\circledR}$ ) [24], lipase B from Candida antarctica (Novozym 435) [25] and Lecitase ${ }^{\mathrm{TM}}$ Ultra, chimeric enzyme produced by the fusion of the genes of the lipase from Thermomyces lanuginosus and the phospholipase $\mathrm{A}_{1}$ from Fusarium oxysporum [26]. The alcoholysis of substrates catalyzed by Lipozyme ${ }^{\circledR}$ and Novozym 435 was carried out in 95\% ethanol [27], and the hydrolysis with Lecitase ${ }^{\mathrm{TM}}$ Ultra was carried out in hexane (Scheme 2) [28]. 

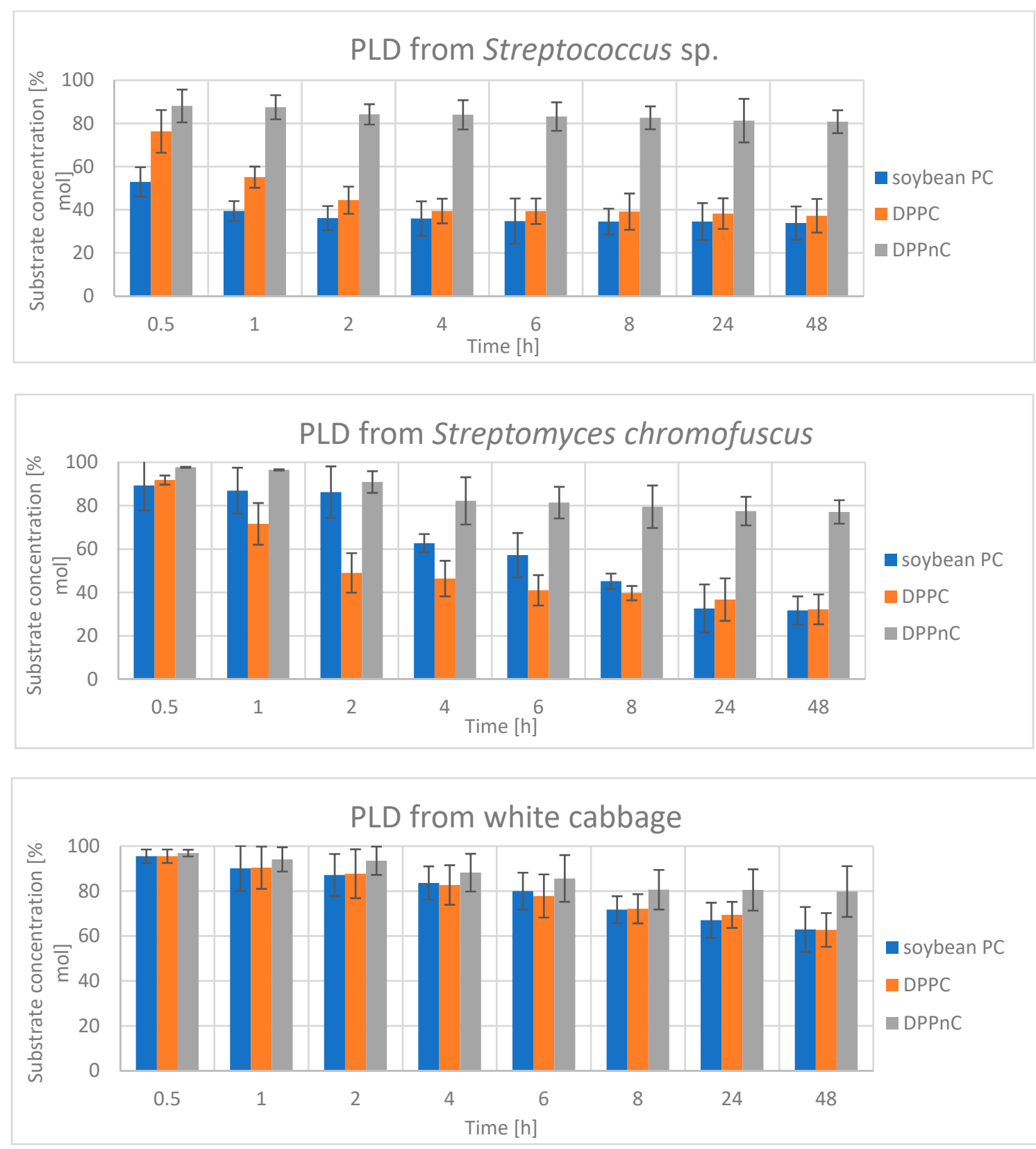

Figure 4. Enzymatic hydrolysis of DPPnC, DPPC and soybean PC by phospholipases D. Results are presented as means \pm standard deviation.

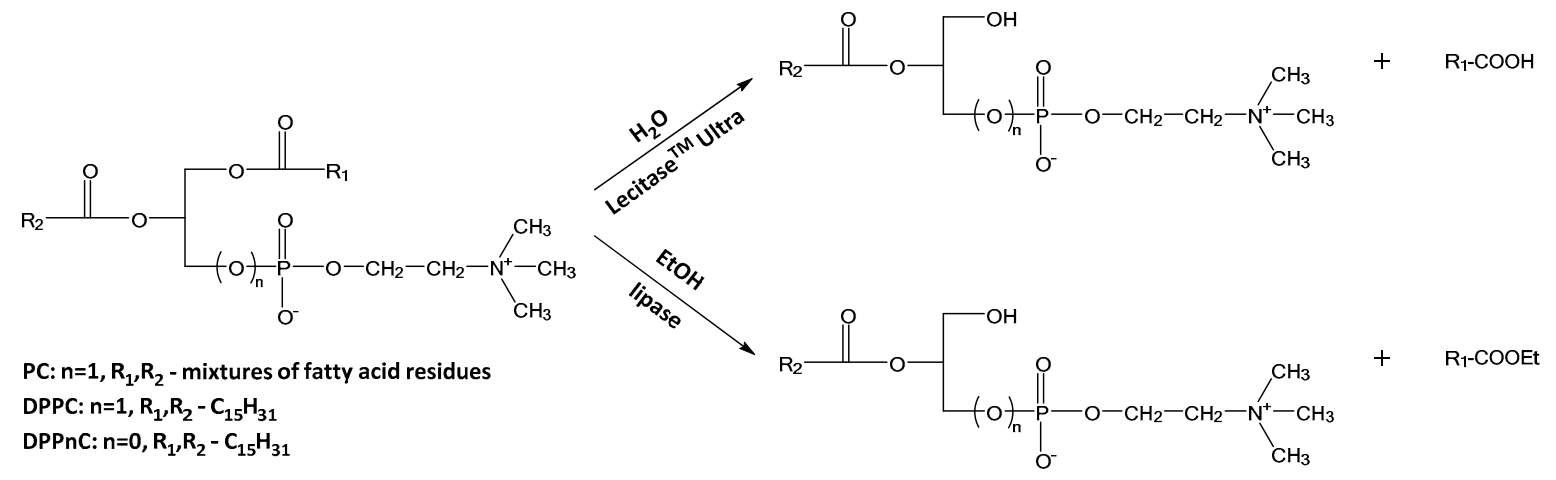

Scheme 2. Hydrolysis of DPPnC, DPPC and soybean PC catalyzed by Lecitase ${ }^{\mathrm{TM}}$ Ultra and ethanolysis catalyzed by lipases. 
The results showed (Figure 2) that in the reaction with Lecitase ${ }^{\circledR}$ Ultra, faster hydrolysis was observed for DPPnC compared to DPPC and natural soybean PC. It was particularly noticeable in the first $4 \mathrm{~h}$ of reaction when the degree of hydrolysis was $44 \%$ for DPPnC, $24 \%$ for DPPC and 19\% for soybean PC.

In the next hours, the hydrolysis rate of the (R)-phosphonolipid significantly decreased, and after $24 \mathrm{~h}$, the contents of DPPnC and DPPC were comparable ( $41 \%$ vs. $45 \%$ ), whereas the content of soybean PC was only $18 \%$. Extending the reaction time to $48 \mathrm{~h}$, no significant changes in the composition of the reaction mixtures were observed.

Ethanolysis of tested substrates catalyzed by immobilized lipases from M. miehei and $C$. antarctica proceeded significantly faster and more efficiently. Phosphono analogue of DPPC reacted faster than DPPC, but slower than natural soybean PC. In the case of Novozym 435, after $6 \mathrm{~h}$ of reaction, the amount of DPPnC, DPPC and soybean PC were $16 \%, 42 \%$ and $5 \%$, respectively, and after $48 \mathrm{~h}$, almost complete ethanolysis of all substrates was observed. Lipozyme ${ }^{\circledR}$ turned out to be the most effective biocatalyst under the reaction conditions used. The course of reaction was similar to that observed for Novozym 435, but the reaction rate was significantly higher in the first $6 \mathrm{~h}$ of process, resulting in $6 \%$ for DPPnC, $18 \%$ for DPPC and only $1 \%$ for soybean PC. After $24 \mathrm{~h}$, the degree of ethanolysis of all substrates exceeded $98 \%$. Higher rates of ethanolysis reaction observed for Lipozyme ${ }^{\circledR}$ and Novozyme 435 can be explained by higher stability of immobilized lipases than the free form of Lecitase ${ }^{\circledR}$ Ultra, which was used for the hydrolysis.

\subsubsection{Hydrolysis Catalyzed by Phospholipases $\mathrm{A}_{2}$}

The enzymatic hydrolysis involving phospholipases $\mathrm{A}_{2}$ from porcine and bovine pancreas were carried out based on the method described by Morgado et al. [29] adapted and used in our laboratory $[30,31]$. Reaction with phospholipase $\mathrm{A}_{2}$ from bee venom was conducted based on the protocol proposed by Florin-Christensen et al. (Scheme 3) [32].

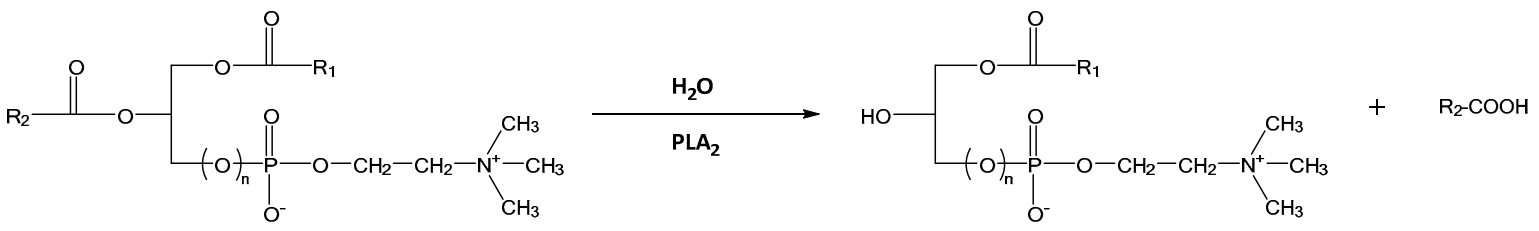

PC: $n=1, R_{1}, R_{2}$ - mixtures of fatty acid residues

DPPC: $n=1, R_{1}, R_{2}-C_{15} H_{31}$

DPPnC: $n=0, R_{1}, R_{2}-C_{15} H_{31}$

Scheme 3. Hydrolysis of DPPnC, DPPC and soybean PC at $s n-2$ position.

Among the studied enzymes from the PLA $\mathrm{A}_{2}$ family, the fastest reaction rates and the highest efficiency of hydrolysis in $s n-2$ position were observed for bovine $\mathrm{PLA}_{2}$ followed by porcine PLA $\mathrm{P}_{2}$ and the least active towards all substrates was bee venom PLA 2 (Figure 3). After $48 \mathrm{~h}$, almost complete conversion of substrates was observed in the case of reactions with both pancreatic enzymes, whereas in the hydrolysis catalyzed by bee venom PLA, $50-60 \%$ of substrates were still unreacted. In the bovine PLA $_{2}$-catalyzed reactions and bee venom $\mathrm{PLA}_{2}$-catalyzed reactions, soybean PC was hydrolyzed at the highest rate. In the porcine $\mathrm{PLA}_{2}$-catalyzed reactions, during the first $4 \mathrm{~h}$ of the process, a higher level of hydrolysis was observed for DPPnC (4). Afterwards, the reaction rate of soybean PC increased to result in almost complete hydrolysis after $8 \mathrm{~h}$ whereas $17 \%$ of DPPnC and $25 \%$ of DPPC were still observed in the reaction mixture.

As in the case of the hydrolysis in $s n-1$ position, hydrolysis of DPPnC in the $s n-2$ position was faster than hydrolysis of DPPC. The highest differences between reaction rates of DPPC and DPPnC were observed for the hydrolysis catalyzed by $\mathrm{PLA}_{2}$ from porcine pancreas. In this case, after $4 \mathrm{~h}$, there was still $73 \%$ of the unreacted DPPC, whereas the amount of unreacted DPPnC was $30 \%$. At the same time, $36 \%$ of DPPC and $27 \%$ of DPPnC 
were determined in the reaction with bovine PLA $\mathrm{P}_{2}$, whereas in the reaction catalyzed by bee venom, PLA $21 \%$ of DPPC and $88 \%$ of DPPnC were detected.

Enantioselective hydrolysis of diethyl 2,3-dipalmitoyloxypropylphosphonate (1) by $\mathrm{PLA}_{2}$ from porcine pancreas was applied in these studies to synthesize $(R)$-DPPnC (Scheme 1). As enzymatic hydrolysis is a convenient method for the resolution of racemic $\alpha$ and $\beta$-hydroxyphosphonate esters [33-36], the hydrolytic activity of phospholipase $A_{2}$ towards DPPnC may be also used for the kinetic resolution of racemic forms of this type of phosphonolipids.

\subsubsection{Hydrolysis Catalyzed by Phospholipases D}

Hydrolysis of the ester bond linking the choline with the residue of phosphatidic acid (in DPPC and soybean PC) and phosphonic acid (in DPPnC) (Scheme 4) was carried out using three phospholipases $\mathrm{D}$ according to the modified protocols described in the literature for individual enzymes. For the experiments with PLD from Streptococcus sp. and PLD from white cabbage, acetate buffer $(\mathrm{pH}=5.6)$ /ethyl acetate system were applied [37], hydrolysis catalyzed by PLD from Streptomyces chromofuscus was carried out in Tris- $\mathrm{HCl}$ buffer $(\mathrm{pH}=8.0) /$ methylene chloride system [38].
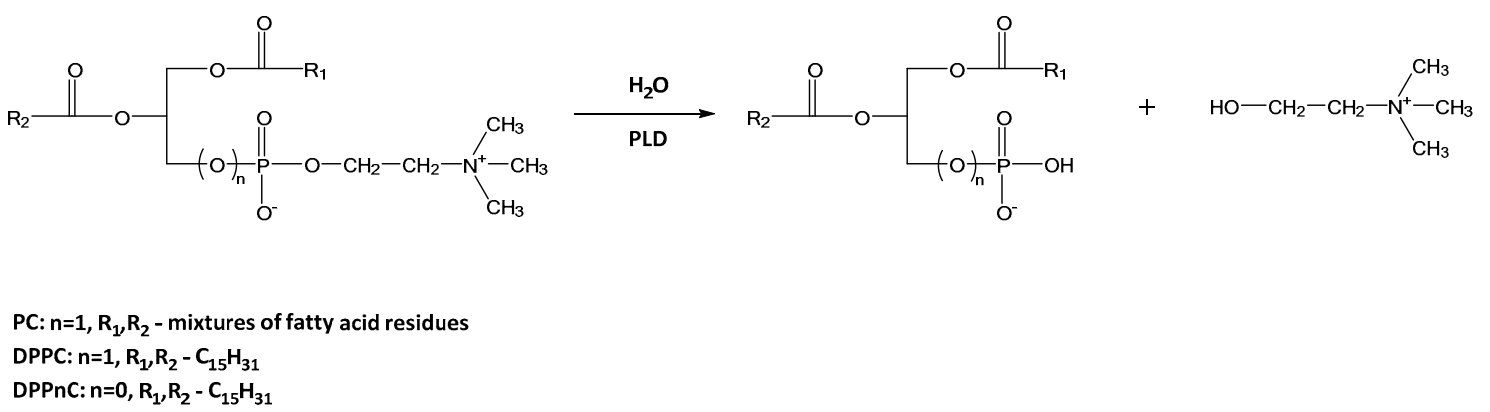

Scheme 4. Hydrolytic cleavage of choline from DPPnC, DPPC and soybean PC.

In the case of PLD-catalyzed reactions, the effect of the presence of C-P bond instead of $\mathrm{C}-\mathrm{O}$ in the linkage between glycerol and phosphoric acid was the most significant. Regardless of the enzyme used, the efficiency of hydrolysis and the reaction rate were clearly lower for DPPnC than for DPPC and natural PC. After $48 \mathrm{~h}$, the conversion of DPPnC was only $19 \%$ and $20 \%$ in the reactions catalyzed by PLD from Streptococcus sp. and PLD from white cabbage, respectively, and was only slightly higher $(23 \%)$ for the reaction with PLD from S. chromofuscus (Figure 4)

In the reaction catalyzed by PLD from Streptococcus sp., soybean PC was hydrolyzed with highest rate, followed by DPPC and DPPnC. After $4 \mathrm{~h}$ of reaction, $36 \%$ of soybean PC, $39 \%$ of DPPC and $84 \%$ of DPPnC were determined, and the composition of reaction mixtures did not change significantly until $48 \mathrm{~h}$. During hydrolysis mediated by PLD from S. chromofuscus, in the first $2 \mathrm{~h}$, the highest reaction rate was observed for DPPC, but after that time, the most efficiently hydrolyzed substrate was soybean PC. As a result, after $48 \mathrm{~h}$, approximately $32 \%$ of both phospholipids were observed. The highest progress of DPPnC hydrolysis was noticed after the first $4 \mathrm{~h}$ of reaction ( $82 \%$ of the substrate in the reaction mixture), whereas for the next $44 \mathrm{~h}$, it decreased to only a small extent (77\% after $48 \mathrm{~h}$ ). The lowest hydrolysis rates and the lowest differences between the hydrolysis of substrates were observed for reactions with PLD from white cabbage. In this case, DPPC and soybean PC were hydrolyzed with comparable reaction rates. Hydrolysis of DPPnC stopped after $8 \mathrm{~h}$ and $80 \%$ of unreacted substrate was observed in reaction mixtures until $48 \mathrm{~h}$ of the process.

To the best of our knowledge, the enzymatic hydrolysis of phosphonolipids with a C-P bond on a glycerol side have not been studied so far. Enzymatic degradation of phosphonic acid analogues of 1,2-dimirystoyl-sn-glycero-3-phosphocholine and 1,2-dimirystoyl-sn- 
glycero-phosphoethanolamine, possessing the C-P bond on the polar side of the molecule, was investigated by Baer and Stanacev [39]. They found that phospholipase C from Clostridium welchii hydrolyzes dimirystoyl L-glyceryl-(2-trimethylammoniumethyl)phosphonate with formation of 1,2-dimirystoyl-sn-glycerol, but under the same experimental conditions $\left(26^{\circ} \mathrm{C}\right.$, Tris- $\mathrm{HCl}$ with mixture diethyl ether/ethanol 98:2, v/v, calcium chloride), this enzyme does not react with dimirystoyl L-glyceryl-(2-aminoethyl)phosphonate.

\section{Materials and Methods}

\subsection{Solvents and Reagents}

Organic solvents (analytical grade) were purchased from Avantor Performance Materials (Gliwice, Poland). Solvents used for liquid chromatography (purity $>99 \%$ ) were obtained from Merck (Darmstadt, Germany). sn-Glycero-3-phosphocholine (GPC, purity > 99\%) was purchased from Bachem (Bubendorf, Switzerland), 4-(N,N-dimethylamino)pyridine (DMAP, purity $\geq 99 \%$ ), $N, N^{\prime}$-dicyclohexylcarbodiimide (DCC, purity 99\%), palmitic acid (purity $>98 \%$ ), dibutyltin(IV) oxide (DBTO, purity $98 \%$ ), triethylamine (TEA, purity $\geq 99.5 \%$ ), dioctyl sulfosuccinate sodium salt (AOT, purity $\geq 97 \%$ ), pyridine (purity $99.8 \%$ ), Trizma ${ }^{\circledR}$ hydrochloride (purity $\geq 99 \%$ ), Trizma ${ }^{\circledR}$ base (purity $\geq 99.9 \%$ ) and Dowex ${ }^{\circledR} 50 \mathrm{~W}$ X8 hydrogen form were purchased from Sigma-Aldrich (St. Louis, MO, USA).

Dowe ${ }^{\circledR} 50 \mathrm{WX} 8$ (pyridinium form) resin was prepared by washing DOWEX 50W X8 $\left(\mathrm{H}^{+}\right.$form) with $50 \%$ aqueous pyridine overnight. After this time, resin was washed with water, $50 \%$ aqueous $\mathrm{MeOH}, \mathrm{MeOH}$ and then mixture $\mathrm{CHCl}_{3}: \mathrm{MeOH}$ :pyridine: $\mathrm{H}_{2} \mathrm{O}$ (3:3:1:1, $\mathrm{v} / \mathrm{v} / \mathrm{v} / \mathrm{v})[40]$.

\subsection{Buffers}

Tris- $\mathrm{HCl}$ buffer $(0.1 \mathrm{M})$ with $\mathrm{Ca}^{2+}$ ions was prepared by dissolving Trizma ${ }^{\circledR}$ hydrochloride $(0.123 \mathrm{~g})$, Trizma ${ }^{\circledR}$ base $(0.513 \mathrm{~g})$ and $\mathrm{CaCl}_{2} \times 2 \mathrm{H}_{2} \mathrm{O}(55.12 \mathrm{~g})$ in distilled water $(400 \mathrm{~mL})$, adjusting $\mathrm{pH}$ at $40{ }^{\circ} \mathrm{C}$ to 8.0 or 8.5 and adding water to the final volume of $500 \mathrm{~mL}$.

Acetic buffer $(\mathrm{pH}=5.6,0.1 \mathrm{M})$ with $\mathrm{Ca}^{2+}$ ions was prepared by dissolving glacial acetic acid $(28.6 \mathrm{~mL})$ and $\mathrm{CaCl}_{2} \times 2 \mathrm{H}_{2} \mathrm{O}(5.88 \mathrm{~g})$ in distilled water $(400 \mathrm{~mL})$, adjusting $\mathrm{pH}$ to 5.6 and adding water to the final volume of $500 \mathrm{~mL}$.

\subsection{Enzymes}

Lecitase ${ }^{\circledR}$ Ultra (10,000 U/mL) was a gift from A/S (Bagsvaerd, Denmark). Lipase B from Candida antarctica (Novozym 435) immobilized on acrylic resin ( $\geq 5,000 \mathrm{U} / \mathrm{g}$ ), lipase from Mucor miehei (Lipozyme $\left.{ }^{\circledR}\right)$ immobilized on macroporous ion exchange resin $(>30 \mathrm{U} / \mathrm{g}$ ), phospholipase $\mathrm{A}_{2}\left(\mathrm{PLA}_{2}\right)$ from porcine pancreas $(10,000 \mathrm{U} / \mathrm{mL})$, phospholipase $\mathrm{A}_{2}\left(\mathrm{PLA}_{2}\right)$ from bovine pancreas $(20 \mathrm{U} / \mathrm{mL})$, phospholipase $\mathrm{A}_{2}\left(\mathrm{PLA}_{2}\right)$ from bee venom (Apis mellifera) (600-2400 U/mg), lyophilized phospholipase D (PLD) from Streptococcus sp., (type VII, $\geq 150 \mathrm{U} / \mathrm{mg}$ ), phospholipase D (PLD) from Streptomyces chromofuscus ( $\geq 50,000 \mathrm{U} / \mathrm{mL})$ and lyophilized phospholipase $\mathrm{D}$ (PLD) from white cabbage $(\geq 100 \mathrm{U} / \mathrm{mL})$ were purchased from Sigma-Aldrich (St. Louis, MO, USA).

\subsection{Enzyme Solutions}

Solutions of PLA $\mathrm{A}_{2}$ from bee venom and PLD from Streptomyces chromofuscus were obtained by dissolving $1 \mathrm{mg}$ or $0.1 \mathrm{mg}$ of commercial enzyme, respectively, in $1 \mathrm{~mL}$ of the mixture of $0.1 \mathrm{M}$ Tris- $\mathrm{HCl}$ buffer $\left(\mathrm{pH}=8.5\right.$ in the case of $\mathrm{PLA}_{2}$ or $\mathrm{pH}=8.0$ in the case of PLD) and glycerol (90:10, v/v) containing 0.1\% of Triton X-100 (w/v).

Solutions of PLD from Streptococcus sp. and PLD from white cabbage were obtained by dissolving $0.1 \mathrm{mg}$ or $1 \mathrm{mg}$ of commercial enzyme, respectively, in $1 \mathrm{~mL}$ of the mixture of $0.1 \mathrm{M}$ acetate buffer $(\mathrm{pH}=5.6)$ and glycerol $(90: 10, \mathrm{v} / \mathrm{v})$ containing $0.1 \%$ of Triton $\mathrm{X}-100(\mathrm{w} / \mathrm{v})$. 


\subsection{Substrates and Products of Enzymatic Hydrolysis}

1,2-Dipalmitoyl-sn-glycero-3-phosphocholine (DPPC) was synthesized according to the standard procedure presented by Smuga et al. [38]. The details of synthesis are given in Supplementary Materials.

Phosphatidylcholine from soybean (soybean PC, purity 98\%) was purchased from Lipoid AG (Steinhausen, Switzerland).

(R)-2,3-Dipalmitoyloxypropylphosphonocholine (DPPnC) was synthesized as described in Sections 3.7 and 3.8.

1-Palmitoyl-2-hydroxy-sn-glycero-3-phosphocholine (1-palmitoyl LPC) and 1-hydroxy2-palmitoyl-sn-glycero-3-phosphocholine (2-palmitoyl LPC) were prepared according to the procedures described earlier by Kiełbowicz et al. [30]. The details of synthesis are given in Supplementary Materials.

Phosphatidic acid monosodium salt (PA-Na, purity $\geq 98 \%$ TLC) was purchased from Sigma-Aldrich (St. Louis, MO, USA).

\subsection{Analytical Methods}

Thin-layer chromatography (TLC) analyses were carried out on silica gel-coated aluminium plates (DC-Alufolien Kieselgel 60 F254) purchased from Merck. The compounds were detected using the $0.05 \%$ primuline solution (acetone:water, $8: 2, \mathrm{v} / \mathrm{v}$ ) and ultraviolet (UV) lamp $(\lambda=365 \mathrm{~nm})$ or using $1 \% \mathrm{Ce}\left(\mathrm{SO}_{4}\right)_{2}, 2 \% \mathrm{H}_{3}\left[\mathrm{P}\left(\mathrm{Mo}_{3} \mathrm{O}_{10}\right)_{4}\right]$ in $10 \% \mathrm{H}_{2} \mathrm{SO}_{4}$ solution and gentle heating. Compounds were purified by column chromatography on silica gel (Kieselgel 60, 0.040-0.063 mm, 230-400 mesh, Merck) with various solvent systems.

High-Performance Liquid Chromatography (HPLC) was carried out on an Ultimate 3000 Dionex chromatograph (Olten, Switzerland) quipped with a DGP-3600A dual-pump fluid control module, TCC-3200 thermostat column compartment and WPS-3000 autosampler. CoronaTM Charged Aerosol Detector (CAD) from ESA Biosciences (Chelmsford, MA, USA) was used with the following parameters: acquisition range $100 \mathrm{pA}$, digital filter set to none, $\mathrm{N}_{2}$ pressure $35 \mathrm{psi}$. The system and data acquisition were carried out using the Chromeleon 6.80 software (Dionex Corporation, Olten, Switzerland). Detailed analysis conditions for particular compounds are given in Supplementary Materials.

Gas chromatography (GC) was carried out on an Agilent 6890N (Agilent, Santa Clara, CA, USA) apparatus equipped with an autosampler and flame ionization detector (FID) with hydrogen as a carrier gas. The system and data acquisition were carried out using GC ChemStation Version A.10.02. Detailed analysis conditions for compound $\mathbf{3}$ are given in Supplementary Materials.

Nuclear magnetic resonance $\left({ }^{1} \mathrm{H}\right.$ NMR, ${ }^{13} \mathrm{C}$ NMR, ${ }^{31} \mathrm{P}$ NMR) spectra were recorded on a Bruker Avance II $600 \mathrm{MHz}$ (Rheinstetten, Germany) for $\mathrm{CDCl}_{3}$ or $\mathrm{CDCl}_{3}: \mathrm{CD}_{3} \mathrm{OD}(2: 1$, $\mathrm{v} / \mathrm{v})$ solutions. Chemical shifts were referenced to the signals of residual solvent $(\delta \mathrm{H}=7.26$, $\delta \mathrm{C}=77.00)$ or to the internal standard of $0.0552 \mathrm{M}$ triphenylphosphate $(\delta \mathrm{P}=-17.02)$.

\subsection{Enantioselective Hydrolysis of rac Diethyl 2,3-Dipalmitoyloxypropylphosphonate (1)}

Mixture of AOT $(0.028 \mathrm{~g}, 0.63 \mu \mathrm{mol})$ in $2 \mathrm{~mL}$ of isooctane was stirred at $40{ }^{\circ} \mathrm{C}$ for $30 \mathrm{~min}$. Then, $160 \mu \mathrm{L}$ of $0.1 \mathrm{M}$ Tris- $\mathrm{HCl}(\mathrm{pH}=8.5)$ containing $\mathrm{CaCl}_{2}(126 \mu \mathrm{mol})$ and phospholipase $\mathrm{A}_{2}\left(\mathrm{PLA}_{2}\right)$ from porcine pancreas $(168 \mu \mathrm{L}, 1675 \mathrm{U})$ was added. In parallel, racemic phosphonate $1(0.25 \mathrm{~g}, 0.36 \mathrm{mmol})$ in $2 \mathrm{~mL}$ of isooctane was heated at $40{ }^{\circ} \mathrm{C}$ with intensive stirring $(750 \mathrm{rpm})$ for $30 \mathrm{~min}$. The reaction was started by the addition of phosphonate 1 solution to the mixture of AOT and PLA 2 . After $48 \mathrm{~h}$, the enzyme was separated by filtration through Celite ${ }^{\circledR} 545$, followed by washing the bed with methanol. Crude product was purified by column chromatography (hexane/ethyl acetate, 1:1). Its physical and spectral data are given below.

(R)- Diethyl 2-hydroxy-3-palmitoyloxypropylphosphonate (2)

Yield 22\%, white powder, TLC: $R_{f}=0.22$ (hexane/ethyl acetate, 1:2); HPLC: $R_{t}=7.51 \mathrm{~min}$, $[\alpha]_{D}^{20}=+1.6\left(\mathrm{c}=2.9\right.$, hexane), ee 87\%; ${ }^{1} \mathrm{H}$ NMR $\left(600 \mathrm{MHz}, \mathrm{CDCl}_{3}: \mathrm{CD}_{3} \mathrm{OD}, 2: 1\right) \delta: 0.85(\mathrm{t}$, $\left.J=7.0 \mathrm{~Hz}, 3 \mathrm{H}, \mathrm{CH}_{3}-16^{\prime}\right), 1.20-1.31\left(\mathrm{~m}, 24 \mathrm{H}, \mathrm{CH}_{2}-4^{\prime}-\mathrm{CH}_{2}-15^{\prime}\right), 1.31(\mathrm{t}, J=7.1 \mathrm{~Hz}, 6 \mathrm{H}, 2 \times-$ 
$\mathrm{OCH}_{2} \mathrm{CH}_{3}$ ), 1.56-1.67 (m, 2H, $\left.\mathrm{CH}_{2}-3^{\prime}\right), 1.99$ and 2.05 (two $\left.\mathrm{m}, 2 \mathrm{H}, \mathrm{CH}_{2}-1\right), 2.35$ (t, $J=7.6 \mathrm{~Hz}$, $\left.2 \mathrm{H}, \mathrm{CH}_{2}-2^{\prime}\right), 3.35(\mathrm{~s}, 1 \mathrm{H},-\mathrm{OH}), 4.00-4.27\left(\mathrm{~m}, 7 \mathrm{H}, 2 \times \mathrm{OCH}_{2} \mathrm{CH}_{3}, \mathrm{CH}_{2}-3, \mathrm{H}-2\right) ;{ }^{13} \mathrm{C} \mathrm{NMR}$ $\left(151 \mathrm{MHz}, \mathrm{CDCl}_{3}: \mathrm{CD}_{3} \mathrm{OD}, 2: 1\right) \delta: 13.24\left(\mathrm{C}-16^{\prime}\right), 15.46\left(\mathrm{~d}, \mathrm{~J}_{\mathrm{C}-\mathrm{P}}=6.2 \mathrm{~Hz}, 2 \times-\mathrm{OCH}_{2} \mathrm{CH}_{3}\right)$, 22.08 and 28.55-31.35 (C-4'-C-15' and C-1), $24.30\left(\mathrm{C}-3^{\prime}\right), 33.48\left(\mathrm{C}-2^{\prime}\right), 61.58\left(\mathrm{~d}, J_{\mathrm{C}-\mathrm{P}}=6.6 \mathrm{~Hz}\right.$, one of $\left.-\mathrm{OCH}_{2} \mathrm{CH}_{3}\right), 61.85\left(\mathrm{~d}, J_{\mathrm{C}-\mathrm{P}}=6.4 \mathrm{~Hz}\right.$, one of $\left.-\mathrm{OCH}_{2} \mathrm{CH}_{3}\right), 63.92\left(\mathrm{~d}, J_{\mathrm{C}-\mathrm{P}}=3.1 \mathrm{~Hz}\right.$, $\mathrm{C}-3), 67.29\left(\mathrm{~d}, \mathrm{~J}_{\mathrm{C}-\mathrm{P}}=14.3 \mathrm{~Hz}, \mathrm{C}-2\right) ; 173.78\left(\mathrm{C}-1^{\prime}\right) ;{ }^{31} \mathrm{P} \mathrm{NMR}\left(243 \mathrm{MHz}, \mathrm{CDCl}_{3}: \mathrm{CD}_{3} \mathrm{OD}, 2: 1\right)$ $\delta: 29.38$.

\subsection{Synthesis of (R)-Diethyl 2,3-Dihydroxypropylphosphonate (3)}

(R)-Diethyl 2-hydroxy-3-palmitoyloxypropylphosphonate (2) $(85 \mathrm{mg}, 0.19 \mathrm{mmol})$ in $3.5 \mathrm{~mL}$ of $0.5 \mathrm{M} \mathrm{NaOH}$ methanolic solution and $0.35 \mathrm{~mL}$ of water was heated under reflux for $1.5 \mathrm{~h}$. Then, the mixture was acidified with $0.1 \mathrm{M} \mathrm{HCl}$ to $\mathrm{pH}=4$, and methanol was evaporated in vacuo. The concentrated mixture was washed with $5 \mathrm{~mL}$ of hexane, and the product was extracted with ethyl acetate $(3 \times 5 \mathrm{~mL})$. Pooled organic layers were dried with anhydrous $\mathrm{MgSO}_{4}$, filtered and the solvent was evaporated. Pure product was isolated by column chromatography $\left(\mathrm{CHCl}_{3} / \mathrm{MeOH}, 15: 1\right)$ to afford pure phosphonate 3 with the following data:

Yield 34\% (13.7 mg), colourless liquid, $\mathrm{R}_{\mathrm{f}}=0.18\left(\mathrm{CHCl}_{3}: \mathrm{MeOH}, 15: 1\right), \mathrm{GC}: \mathrm{Rt}=6.29 \mathrm{~min}$; $[\alpha]_{D}^{20}=-8.7(\mathrm{c}=0.4, \mathrm{EtOH}), e e \quad 87 \%$, (lit. [23] $[\alpha]_{D}^{25}=-12.2(\mathrm{c}=4.1$, EtOH, for enantiomerically pure $(R)-3)$. Spectroscopic data were in accordance with literature [16].

\subsection{Synthesis of (R)-Diethyl 2,3-Dipalmitoyloxypropylphosphonate [(R)-1)]}

$\mathrm{N}, \mathrm{N}^{\prime}$-dicyclohexylcarbodiimide (DCC, $289 \mathrm{mg}, 1.40 \mathrm{mmol}$ ) was dissolved in dry $\mathrm{CH}_{2} \mathrm{Cl}_{2}(2 \mathrm{~mL})$ and added to a mixture of phosphonate $(R)-2(400 \mathrm{mg}, 0.89 \mathrm{mmol}), 4-$ (dimethylamino)pyridine (DMAP) $(81.4 \mathrm{mg}, 0.67 \mathrm{mmol})$ and palmitic acid (341.9 $\mathrm{mg}$, $1.33 \mathrm{mmol})$ in dry $\mathrm{CH}_{2} \mathrm{Cl}_{2}(7 \mathrm{~mL})$. The suspension was stirred at room temperature under nitrogen for $48 \mathrm{~h}$. After this time, the precipitate was removed by filtration, while the crude reaction mixture was dissolved in $\mathrm{CHCl}_{3}: \mathrm{MeOH}: \mathrm{H}_{2} \mathrm{O}(5: 4: 1, \mathrm{v} / \mathrm{v} / \mathrm{v})$, followed by the addition of Dowex 50 WX 8 ion exchange resin in $\mathrm{H}+$ form to remove DMAP. After $30 \mathrm{~min}$ of gentle stirring, the resin was removed by filtration and the solvent was evaporated under reduced pressure. The crude product $(R)-\mathbf{1}$ was purified by column chromatography (silica gel, hexane: ethyl acetate, 2:1). Its physical data are given below:

Yield $94 \%\left(576 \mathrm{mg}\right.$ ), white powder, $\mathrm{R}_{\mathrm{f}}=0.35$ (hexane: ethyl acetate, 2:1, v/v), HPLC: $\mathrm{R}_{\mathrm{t}}=9.90 \mathrm{~min},[\alpha]_{D}^{20}=-0.58$ (c = 0.5, hexane), ee $87 \%$, spectroscopic data were in accordance with literature report [16].

\subsection{Synthesis of (R)-2,3-Dipalmitoyloxypropylphosphonocholine (DPPnC, 4)}

To dry (R)-diethyl 2,3-dipalmitoyloxypropylphosphonate [(R)-1)] (550 mg, $0.80 \mathrm{mmol}$ ) dissolved in dry $\mathrm{CH}_{2} \mathrm{Cl}_{2}(3.15 \mathrm{~mL})$, trimethylsilane bromide $(1.05 \mathrm{~mL}, 8.0 \mathrm{mmol})$ was added under nitrogen with continuous stirring. The reaction mixture was stirred for $4 \mathrm{~h}$ and concentrated by evaporating the solvent under reduced pressure. Aqueous $\mathrm{MeOH}(95 \%, 20 \mathrm{~mL})$ was added to the residue and stirred at room temperature for $1 \mathrm{~h}$. After re-evaporation under reduced pressure, the residue was dissolved in $1 \mathrm{~mL}$ of $\mathrm{CHCl}_{3}: \mathrm{MeOH}: \mathrm{H}_{2} \mathrm{O}$ mixture $(5: 4: 1, \mathrm{v} / \mathrm{v} / \mathrm{v})$ and eluted through a column containing $5 \mathrm{~mL}$ of Dowex $50 \mathrm{WX} 8$ ion exchange resin in proton form $\left(\mathrm{H}^{+}\right)$. After evaporation of the solvent, the residue was suspended in $5 \mathrm{~mL}$ of $\mathrm{CHCl}_{3}: \mathrm{MeOH}:$ pyridine: $\mathrm{H}_{2} \mathrm{O}$ mixture (3:3:1:1, v/v/v/v), applied to a column filled with ion exchange resin containing Dowex ${ }^{\circledR} 50 \mathrm{WX} 8$ salt pyridinium and eluted with $10 \mathrm{~mL}$ of $\mathrm{CHCl}_{3}: \mathrm{MeOH}$ :pyridine: $\mathrm{H}_{2} \mathrm{O}$ mixture. The solvents were then evaporated several times under reduced pressure using alternately Folch solvent $\left(\mathrm{CHCl}_{3}: \mathrm{MeOH}\right.$, $2: 1, \mathrm{v} / \mathrm{v}$ ) and anhydrous benzene. The residue was dissolved under nitrogen in $25 \mathrm{~mL}$ of dried pyridine; then, $384 \mathrm{mg}(1.41 \mathrm{mmol})$ of choline tosylate and $290 \mathrm{mg}(1.40 \mathrm{mmol})$ of DCC were added. After $24 \mathrm{~h}$ of reaction, $142 \mathrm{mg}(0.69 \mathrm{mmol})$ of DCC were added, and stirring was continued for another $24 \mathrm{~h}$. After this time, the solvent was evaporated under reduced pressure, and the crude product was purified by column chromatography 
(silica gel, $\mathrm{CHCl}_{3}: \mathrm{MeOH}: \mathrm{H}_{2} \mathrm{O}, 65: 25: 3, \mathrm{v} / \mathrm{v} / \mathrm{v}$ ) to give pure DPPnC (4) with the following physical data:

Yield 51\% (293 mg), white powder, $\mathrm{R}_{\mathrm{f}}=0.41\left(\mathrm{CHCl}_{3}: \mathrm{MeOH}: \mathrm{H}_{2} \mathrm{O}, 65: 25: 2\right)$, HPLC: $\mathrm{R}_{\mathrm{t}}=11.16 \mathrm{~min},[\alpha]_{D}^{20}=+8.1\left(\mathrm{c}=0.4, \mathrm{CHCl}_{3}\right)$, ee $87 \%$, spectroscopic data were in accordance with literature report [16].

\subsection{Enzymatic Hydrolysis of DPPC, DPPnC and Soybean PC}

Reactions were carried out for $48 \mathrm{~h}$ in the heating block using $1.5 \mathrm{~mL}$ vials. After several time intervals, $8 \mu \mathrm{L}$ of reaction mixture were withdrawn, filtered through the diatomaceous earth $\left(\right.$ CELITE $\left.^{\circledR} 545\right)$ and rinsed with methanol. The filtrates were transferred to new vials and analyzed by HPLC. Experiments for particular substrates and enzymes were performed in triplicates. For each experiment, a blank test (without enzyme) was performed, confirming the stability of the substrates in the reaction medium throughout the experiment.

\subsubsection{Reactions Catalyzed by Lecitase ${ }^{\circledR}$ Ultra}

Substrate $(20 \mathrm{nmol})$ was dissolved in $0.6 \mathrm{~mL}$ of hexane followed by the addition $2.0 \mu \mathrm{L}$ $(20 \mathrm{U})$ of Lecitase ${ }^{\circledR}$ Ultra and $15 \mu \mathrm{L}$ of water. The reaction mixtures were stirred at $50{ }^{\circ} \mathrm{C}$.

\subsubsection{Reactions Catalyzed by Lipases}

Substrate $(20 \mathrm{nmol})$ was dissolved in $0.6 \mathrm{~mL}$ of $95 \%$ ethanol and $10 \mathrm{mg}(20 \mathrm{U})$ of Novozym 435 or $150 \mathrm{mg}(4.5 \mathrm{U})$ of Lipozyme ${ }^{\circledR}$ were added, respectively. The reaction mixtures were stirred at $30^{\circ} \mathrm{C}$.

\subsubsection{Reactions Catalyzed by Phospholipases $\mathrm{A}_{2}$}

Solutions of substrate $(20 \mathrm{nmol})$ in $0.45 \mathrm{~mL}$ of isooctane and AOT $(1.5 \mathrm{mg}, 3 \mu \mathrm{mol})$ in $0.45 \mathrm{~mL}$ of isooctane were incubated in separate vials at $40^{\circ} \mathrm{C}$ for $30 \mathrm{~min}$. After that time, $9 \mu \mathrm{L}$ of $0.1 \mathrm{M}$ Tris- $\mathrm{HCl}$ buffer $\left(\mathrm{pH}=8.5\right.$ ) containing $0.75 \mathrm{M} \mathrm{CaCl}_{2}, 9 \mu \mathrm{L}$ (91 U) of $\mathrm{PLA}_{2}$ from porcine pancreas and, finally, the substrate solution were added to the AOT solution. The reaction mixtures were stirred at $40{ }^{\circ} \mathrm{C}$.

A similar procedure was applied for reactions catalyzed by $\mathrm{PLA}_{2}$ bovine pancreas and $\mathrm{PLA}_{2}$ from bee venom using $4.5 \mathrm{mg}(90 \mathrm{U})$ or $0.1 \mathrm{mg}(60 \mathrm{U})$, respectively. In the case of $\mathrm{PLA}_{2}$ from bee venom, the reaction mixtures were carried out at $25^{\circ} \mathrm{C}$.

\subsubsection{Reactions Catalyzed by PLD from Streptomyces chromofuscus}

Substrate $(20 \mathrm{nmol})$ was dissolved in $0.3 \mathrm{~mL}$ of $200 \mathrm{mM}$ Tris- $\mathrm{HCl}(\mathrm{pH}=8.0)$ with $80 \mathrm{mM} \mathrm{CaCl}_{2}$. After obtaining a homogeneous suspension, $0.3 \mathrm{~mL}$ of $\mathrm{CH}_{2} \mathrm{Cl}_{2}$ and PLD solution $(20 \mu \mathrm{L}, 10 \mathrm{U})$ were added. The reaction mixtures were stirred at $35^{\circ} \mathrm{C}$.

\subsubsection{Reactions Catalyzed by PLD from Streptococcus sp. and PLD from White Cabbage}

Substrate $(20 \mathrm{nmol})$ was dissolved in $0.3 \mathrm{~mL}$ of $0.1 \mathrm{M}$ acetate buffer $(\mathrm{pH}=5.6)$ containing $80 \mathrm{mM} \mathrm{CaCl}_{2}$. After a homogeneous suspension was obtained, $0.3 \mathrm{~mL}$ of ethyl acetate and $67.5 \mu \mathrm{L}(10 \mathrm{U})$ of PLD from Streptococcus sp. solution or $100 \mu \mathrm{L}(10 \mathrm{U})$ of PLD from white cabbage solution were added. The reaction mixtures were stirred at $30^{\circ} \mathrm{C}$.

\section{Conclusions}

The results showed that the presence of C-P bond between glycerol and phosphoric acid residue in DPPnC increases the rate of enzymatic hydrolysis or ethanolysis of ester bonds at the $s n-1$ and $s n-2$ position. The opposite effect was observed in the PLD-catalyzed hydrolysis of the ester bond between phosphonate acid and choline. The most significant changes in the hydrolysis rates were observed for reaction with PLD from Streptococcus sp. and PLD from S. chromofuscus. In these cases, DPPnC was hydrolyzed approximately two times slower than DPPC and soybean PC. 
The evaluation of the susceptibility of model compound DPPnC towards selected enzymes showed a potential possibility of using phosphonolipids as carriers of bioactive molecules that, instead of choline, can be bounded with diacylpropylphosphonic acid (DPPnA). A slow rate of hydrolysis of the ester linkage between phosphonic acid and choline, caused by the presence of the C-P bond in the structure of DPPnC-like compounds, may result in the prolonged release of the active molecule. It may result in reducing its necessary dose and limit its toxicity, which gives perspective to designing a new class of phosphonolipid prodrugs.

Supplementary Materials: The following are available online at https:/ /www.mdpi.com/2073-4 344/11/1/129/s1. Conditions of HPLC analysis; 2. Conditions of GC analysis; 3. Synthesis of 1,2dipalmitoyl-sn-glycero-3-phosphocholine (DPPC); 4. Synthesis of 1-palmitoyl-2-hydroxy-sn-glycero3-phosphocholine (1-palmitoyl LPC) and 1-hydroxy-2-palmitoyl-sn-glycero-3-phosphocholine (2palmitoyl LPC); Table S1: Concentration of substrates during hydrolysis or ethanolysis of soybean PC, DPPC and (R)-DPPnC in $s n-1$ position catalyzed by lipases and Lecitase ${ }^{\circledR}$ Ultra; Table S2: Concentration of substrates during hydrolysis of soybean PC, DPPC and (R)-DPPnC in $s n-2$ position by phospholipases $\mathrm{A}_{2}$; Table S3: Concentration of substrates during hydrolysis of soybean PC, DPPC and $(R)$-DPPnC by phospholipases D.

Author Contributions: Conceptualization, P.M. and C.W.; investigation, P.M.; writing-original draft, W.G., C.W. and P.M.; writing - review and editing, P.M., W.G. and C.W. All authors have read and agreed to the published version of the manuscript.

Funding: This research was financed by the statutory activities of the Department of Chemistry, Wrocław University of Environmental and Life Sciences. Article Processing Charge (APC) was financed under the Leading Research Groups support project from the subsidy increased for the period 2020-2025 in the amount of $2 \%$ of the subsidy referred to Art. 387 (3) of the Law of 20 July 2018 on Higher Education and Science, obtained in 2019.

Institutional Review Board Statement: Not applicable.

Informed Consent Statement: Not applicable.

Data Availability Statement: The data presented in this study are available in Supplementary Materials.

Conflicts of Interest: The authors declare no conflict of interest.

\section{References}

1. Liang, C.R.; Rosenberg, H. The biosynthesis of the phosphonic analogue of cephalin in Tetrahymena. Biochim. Biophys. Acta (BBA) Lipids Lipid Metab. 1966, 125, 548-562. [CrossRef]

2. Mason, W.T. Isolation and characterization of the lipids of the sea anemone, Metridium senile. Biochim. Biophys. Acta 1972, 280, 538-544. [CrossRef]

3. Mukhamedova, K.S.; Glushenkova, A.I. Natural phosphonolipids. Chem. Nat. Compd. 2000, 36, 329-341. [CrossRef]

4. Moschidis, M.; Demopoulos, C.; Kritikou, L. Isolation of hens' phosphonolipids by thin-layer chromatography, their identification and silicic acid column chromatographic separation. J. Chromatogr. 1984, 292, 473-478. [CrossRef]

5. Floch, V.; Legros, N.; Loisel, S.; Guillaume, C.; Guilbot, J.; Benvegnu, T.; Ferrieres, V.; Plusquellec, D.; Ferec, C. New biocompatible cationic amphiphiles derivative from glycine betaine: A novel family of efficient nonviral gene transfer agents. Biochem. Biophys. Res. Commun. 1998, 251, 360-365. [CrossRef]

6. Rosenthal, F.; Chodsky, V.; Han, C.H.; Long, T.; Jewish, I.; Igth, M.; Park, N.H. Diether phosphinate lecithin: Chemical synthesis and effects on phospholipase C. Biochim. Biophys. Acta 1969, 187, 385-392. [CrossRef]

7. Huang, W.; Zhang, H.; Davrazou, F.; Kutateladze, T.G.; Shi, X.; Gozani, O.; Prestwich, G.D. Stabilized phosphatidylinositol-5phosphate analogues as ligands for the nuclear protein ING2: Chemistry, biology, and molecular modeling. J. Am. Chem. Soc. 2007, 129, 6498-6505. [CrossRef]

8. Baer, E.; Stanacev, N.Z. Phosphonolipids. I. Synthesis of a phosphonic acid analogue of cephalin. J. Biol. Chem. 1964, 239, 3209-3214. [CrossRef]

9. Baer, E.; Stanacev, N.Z. Phosphonolipids. II. Synthesis of dialkyl L-alfa-glyceryl-(2-aminoethyl) phosphonates. J. Biol. Chem. 1965, 240, 44-48. [CrossRef]

10. Fields, S.C. Synthesis of natural products containing a C-P bond. Tetrahedron 1999, 55, 12237-12273. [CrossRef]

11. Xu, Y.; Prestwich, G.D. Synthesis of chiral ( $\alpha, \alpha$-difluoroalkyl) phosphonate analogues of (Lyso) phosphatidic acid via hydrolytic kinetic resolution. Org. Lett. 2002, 4, 4021-4024. [CrossRef] [PubMed] 
12. Xu, Y.; Qian, L.; Prestwich, G.D. Synthesis of monofluorinated analogues of lysophosphatidic acid analogues were enantiospecifically prepared from chiral protected glycerol synthons, and the surprising enantiospecific and receptor-specific biological readouts, with one compound showing. J. Org. Chem. 2003, 68, 5320-5330. [CrossRef] [PubMed]

13. Xu, Y.; Qian, L.; Prestwich, G.D. Synthesis of $\alpha$-fluorinated phosphonates from $\alpha$-fluorovinylphosphonates: A new route to analogues of lysophosphatidic acid. Org. Lett. 2003, 5, 2267-2270. [CrossRef] [PubMed]

14. Xu, Y.; Aoki, J.; Shimizu, K.; Umezu-Goto, M.; Hama, K.; Takanezawa, Y. Structure-Activity relationships of fluorinated lysophosphatidic acid. J. Med. Chem. 2005, 48, 3319-3327. [CrossRef] [PubMed]

15. Prestwich, G.D.; Gajewiak, J.; Zhang, H.; Xu, X.; Yang, G.; Serban, M. Phosphatase-resistant analogues of lysophosphatidic acid: Agonists promote healing, antagonists and autotaxin inhibitors treat cancer. Biochim. Biophys. Acta Mol. Cell Biol. Lipids 2008, 1781, 588-594. [CrossRef] [PubMed]

16. Mituła, P.; Wawrzeńczyk, C. Synthesis of a series of new racemic [2,3-bis(acyloxy)propyl]phosphonocholines. Arkivoc 2012, 2012, 216-232. [CrossRef]

17. De Maria, L.; Vind, J.; Oxenbøll, K.M.; Svendsen, A.; Patkar, S. Phospholipases and their industrial applications. Appl. Microbiol. Biotechnol. 2007, 74, 290-300. [CrossRef]

18. Borrelli, G.M.; Trono, D. Recombinant lipases and phospholipases and their use as biocatalysts for industrial applications. Int. J. Mol. Sci. 2015, 16, 20774-20840. [CrossRef]

19. Adlercreutz, P. Immobilisation and application of lipases in organic media. Chem. Soc. Rev. 2013, 42, 6406-6436. [CrossRef]

20. Bornscheuer, U.T. Enzymes in lipid modification: Past achievements and current trends. Eur. J. Lipid Sci. Technol. 2014, 116, 1322-1331. [CrossRef]

21. Angajala, G.; Pavan, P.; Subashini, R. Lipases: An overview of its current challenges and prospectives in the revolution of biocatalysis. Biocatal. Agric. Biotechnol. 2016, 7, 257-270. [CrossRef]

22. Carvalho, A.C.L.D.M.; Fonseca, T.D.S.; de Mattos, M.C.; de Oliveira, M.D.C.F.; de Lemos, T.M.L.G.; Molinari, F.; Romano, D.; Serra, I. Recent advances in lipase-mediated preparation of pharmaceuticals and their intermediates. Int. J. Mol. Sci. 2015, 16, 29682-29716. [CrossRef] [PubMed]

23. Baer, E.; Basu, H. Phosphonic acid analogues of carbohydrate metabolites. I. Synthesis of L-and D-dihydroxypropylphosphonic acid. Can. J. Biochem. 1969, 47, 955-960. [CrossRef] [PubMed]

24. Rodrigues, R.C.; Fernandez-Lafuente, R. Lipase from Rhizomucor miehei as an industrial biocatalyst in chemical process. J. Mol. Catal. B Enzym. 2010, 64, 1-22. [CrossRef]

25. Ortiz, C.; Ferreira, M.L.; Barbosa, O.; Dos Santos, J.C.S.; Rodrigues, R.C.; Berenguer-Murcia, Á.; Briand, L.E.; Fernandez-Lafuente, R. Novozym 435: The "perfect" lipase immobilized biocatalyst? Catal. Sci. Technol. 2019, 9, 2380-2420. [CrossRef]

26. Virgen-Ortíz, J.J.; dos Santos, J.C.S.; Ortiz, C.; Berenguer-Murcia, Á.; Barbosa, O.; Rodrigues, R.C.; Fernandez-Lafuente, R. Lecitase ultra: A phospholipase with great potential in biocatalysis. Mol. Catal. 2019, 473, 110405. [CrossRef]

27. Adlercreutz, D.; Wehtje, E. An enzymatic method for the synthesis of mixed-acid phosphatidylcholine. JAOCS J. Am. Oil Chem. Soc. 2004, 81, 553-557. [CrossRef]

28. Lim, C.W.; Kim, B.H.; Kim, I.H.; Lee, M.W. Modeling and optimization of phospholipase A $_{1}$-catalyzed hydrolysis of phosphatidylcholine using response surface methodology for lysophosphatidylcholine production. Biotechnol. Prog. 2015, 31 , 35-41. [CrossRef]

29. Morgado, M.A.P.; Cabral, J.M.S.; Prazeres, D.M.F. Hydrolysis of lecithin by phospholipase $\mathrm{A}_{2}$ in mixed reversed micelles of lecithin and sodium dioctyl sulphosuccinate. J. Chem. Technol. Biotechnol. 1995, 63, 181-189. [CrossRef]

30. Kiełbowicz, G.; Gładkowski, W.; Chojnacka, A.; Wawrzeńczyk, C. A simple method for positional analysis of phosphatidylcholine. Food Chem. 2012, 135, 2542-2548. [CrossRef]

31. Kiełbowicz, G.; Chojnacka, A.; Gliszczyńska, A.; Gładkowski, W.; Kłobucki, M.; Niezgoda, N.; Wawrzeńczyk, C. Positional analysis of phosphatidylcholine and phosphatidylethanolamine via LC with a charged aerosol detector. Talanta 2015, 141, 137-142. [CrossRef] [PubMed]

32. Florin-Christensen, J.; Narvaez-Vasquez, J.; Florin-Christensen, M.; Ryan, C.A. A method for distinguishing 1-acyl from 2-acyl lysophosphatidylcholines generated in biological systems. Anal. Biochem. 1999, 276, 13-17. [CrossRef] [PubMed]

33. Drescher, M.; Li, Y.F.; Hammerschmidt, F. Enzymes in organic chemistry, part 2: Lipase-catalysed hydrolysis of 1-acyloxy-2arylethylphosphonates and synthesis of phosphonic acid analogues of L-phenylalanine and L-tyrosine. Tetrahedron 1995, 51, 4933-4946. [CrossRef]

34. Zhang, Y.; Li, Z.; Yuan, C. Candida rugosa lipase-catalyzed enantioselective hydrolysis in organic solvents. Convenient preparation of optically pure 2-hydroxy-2-arylethanephosphonates. Tetrahedron Lett. 2002, 43, 3247-3249. [CrossRef]

35. Kolodiazhnyi, O.I. Enzymatic synthesis of organophosphorus compounds. Russ. Chem. Rev. 2011, 80, 883-910. [CrossRef]

36. Majewska, P.; Serafin, M.; Klimek-Ochab, M.; Brzezińska-Rodak, M.; Żymańczyk-Duda, E. Lipases and whole cell biotransformations of 2-hydroxy-2-(ethoxyphenylphosphinyl)acetic acid and its ester. Bioorg. Chem. 2016, 66, 21-26. [CrossRef]

37. Hosokawa, M.; Shimatani, T.; Kanada, T.; Inoue, Y.; Takahashi, K. Conversion to docosahexaenoic acid-containing phosphatidylserine from squid skin lecithin by phospholipase D-mediated transphosphatidylation. J. Agric. Food Chem. 2000, 48, $4550-4554$. [CrossRef]

38. Smuga, D.A.; Smuga, M.; Świzdor, A.; Panek, A.; Wawrzeńczyk, C. Synthesis of dehydroepiandrosterone analogues modified with phosphatidic acid moiety. Steroids 2010, 75, 1146-1152. [CrossRef] 
39. Baer, E.; Stanacev, N.Z. Phosphonolipids VI. Chemical and enzymatic degradation for study of structure. Can. J. Biochem. 1966, 44, 893-897. [CrossRef]

40. Ryu, E.K.; Ross, R.J.; Matsushita, T.; MacCoss, M.; Hong, C.I.; West, C.R. Phospholipid-nucleoside conjugates. 3. Syntheses and preliminary biological evaluation of 1- $\beta$-D-arabinofuranosylcytosine $5^{\prime}$-monophosphate-L-1,2-dipalmitin and selected 1- $\beta$-D-arabinofuranosylcytosine 5'-diphosphate-L-1,2-diacylglycerols. J. Med. Chem. 1982, 25, 1322-1329. [CrossRef] 